\title{
Cytotoxic Effect of Methanol Extracts and Partitions of Two Mexican Desert Plants against the Murine Lymphoma L5178Y-R
}

\author{
Ramiro Quintanilla-Licea ${ }^{*}$, Ricardo Gomez-Flores ${ }^{2}$, Mario Ángel Samaniego-Escamilla1, \\ Humberto Carlos Hernández-Martínez², Patricia Tamez-Guerra², \\ Rolando Morado-Castillo' \\ ${ }^{1}$ Laboratorio de Fitoquímica, Facultad de Ciencias Biológicas, Universidad Autónoma de Nuevo León, UANL, \\ San Nicolás de los Garza, México \\ ${ }^{2}$ Laboratorio de Inmunobiología y Virología, Facultad de Ciencias Biológicas, Universidad Autónoma de Nuevo \\ León, UANL, San Nicolás de los Garza, México \\ Email: *ramiro.quintanillalc@uanl.edu.mx
}

Received 14 June 2016; accepted 31 July 2016; published 3 August 2016

Copyright (C) 2016 by authors and Scientific Research Publishing Inc.

This work is licensed under the Creative Commons Attribution International License (CC BY). http://creativecommons.org/licenses/by/4.0/

c) (i) Open Access

\section{Abstract}

Pachycereus marginatus (DC.) Britton \& Rose and Ibervillea sonorae (S. Watson) Greene have been used in the Mexican traditional medicine for the treatment of various diseases, including cancer. The present study aims to investigate the cytotoxic activity of these plants against a murine lymphoma. Soxhlet extraction of dried and powdered plant material was performed with methanol. Also, a further partitioning of these methanolic extracts with hexane and ethyl acetate was achieved. The in vitro cytotoxic activity against the murine lymphoma L5178Y-R cell line was assessed via the colorimetric MTT assay. The methanol extract from $P$. marginatus exhibited high cytotoxic activity (up to $94 \%$ ) at concentrations ranging from 3.9 to $500 \mu \mathrm{g} / \mathrm{mL}$; however, hexane and ethyl acetate partitions from this methanolic extract showed lower but significant $(p<0.05)$ concentration-dependent cytotoxicity (hexane partition up to $94 \%$ at $500 \mu \mathrm{g} / \mathrm{mL}$; ethyl acetate partition up to $94 \%$ at $65.5 \mu \mathrm{g} / \mathrm{mL}$ ). The methanolic extract and partitions derived from $I$. sonorae also showed significant $(p<0.05)$ and concentration-dependent cytotoxicity against L5178Y-R cells at concentrations ranging from 7.81 to $500 \mu \mathrm{g} / \mathrm{mL}$ (methanolic extract up to $63 \%$ at $500 \mu \mathrm{g} / \mathrm{mL}$; hexane partition up to $76 \%$ at $250 \mu \mathrm{g} / \mathrm{mL}$; ethyl acetate partition up to $73 \%$ at $500 \mu \mathrm{g} / \mathrm{mL}$ ). These results demonstrate that the methanol extracts and partitions from $P$. marginatus and $I$. sonorae possess significant cytotoxic activity against the murine lymphoma L5178Y-R and validate the ethnobotanical use of these plants for the treatment of diseases consistent with cancer symptomatology. Previous scientific reports describe the isolation of isoquinoline alkaloids of $P$. margi-

\footnotetext{
"Corresponding author.

How to cite this paper: Quintanilla-Licea, R., Gomez-Flores, R., Samaniego-Escamilla, M.Á., Hernández-Martínez, H.C., Tamez-Guerra, P. and Morado-Castillo, R. (2016) Cytotoxic Effect of Methanol Extracts and Partitions of Two Mexican Desert Plants against the Murine Lymphoma L5178Y-R. American Journal of Plant Sciences, 7, 1521-1530.

http://dx.doi.org/10.4236/ajps.2016.711143
} 
natus as well as cucurbitacins from $I$. sonorae, phytochemicals that could be responsible for their observed cytotoxic activity in this research. The direct extraction with methanol of medicinal plants allows extracting of both high and low-polarity compounds, contrary to the simple extraction with water that only allows obtaining compounds of high polarity. The subsequent partition of the methanol extract with a solvent of low polarity (hexane) and another of medium polarity (ethyl acetate) allows making a preliminary fractionation of the bioactive molecules present in the plant that will facilitate the bioguided chromatographic isolation of the pure compounds responsible for the biological activity of the plant.

\section{Keywords}

\section{Anticancer Plants, Cactaceae, Cucurbitaceae, Mexican Medicinal Plants, Extracts, Partitions}

\section{Introduction}

Cancer is a worldwide disease that is one of the leading causes of death [1]. In 2012 there was reported an estimate of 14.1 million adults diagnosed with cancer around the world and 8.2 million of deaths from this condition in the same year [2]. Its ascending frequency and global distribution, ignoring gender or age, encourage researchers to seek new alternatives that contribute to actual anticancer therapies [3].

As in other developing countries, cancer incidence and mortality have been on the rise in Mexico [4], where a large section of the population uses herbal medicines for the treatment of several diseases [5]. Three hundred plant species belonging to 90 botanical families used for cancer treatment have been recorded in Mexico, of which only 181 have been experimentally analyzed. The remaining 119 plant species are being used in the empirical treatment of diseases consistent with cancer symptomatology [6].

Some studies have reported the use of aqueous extracts of Cactaceae and Cucurbitaceae, recollected in desert areas of North Mexico, for the treatment of malignant and benign tumors. The patients received phytotherapy as only causal treatment. This therapeutic approach has demonstrated no adverse reactions or clinical and laboratory events, improving the quality of life and survival [7].

The aim of this work is to evaluate the possible cytotoxic activity of Pachycereus marginatus (DC.) Britton \& Rose (cactacea) and Ibervillea sonorae (S. Watson) Greene (cucurbitacea) against the L5178Y-R murine lymphoma. These plants are commonly found in popular markets in Mexico, and their ethnobotanical use includes the treatment of cancer [6], but until now there are no sufficient scientific studies available related to their use against said disease.

\subsection{Pachycereus marginatus}

Pachycereus marginatus (Figure 1(a)) is a columnar cactus known in Mexico as “Órgano, Chilayo or Orégano de zopilote" [8] [9], and it is used popularly as living fence. Flowers and fruits are edible. From the stems a dye is prepared for hair coloring, giving an intense black color [10]. The bark is used for the treatment of kidney and bladder problems in the form of poultices placed at the height of the affected region. The sap of the plant is rubbed on the skin in case of loss of hair, skin infections and dryness problems. It is also used as a disinfectant and for the healing of wounds [11]. P. marginatus is often confused with Lophocereus schottii (Engelm.) Britton \& Rose, species used by the Mayos tribe of the Mexican State of Sonora for the treatment of cancer [12] [13].

\subsection{Ibervillea sonorae}

Ibervillea sonorae (Figure 1(b)), popularly called in Mexico "Guareque, Wareque, Wareke, Guereque or Wereke", is an interesting Cucurbitaceae because of the rapid change in its ethnobotanical use [14] [15]. The root of this plant was considered an effective therapeutic resource in dermatological care in the indigenous area mayoyoreme in the Mexican State of Sinaloa and oral ingestion was not advisable, as being a plant with an extremely bitter taste and cathartic activity [16]. As of the nineties of the last century the use of the Wereke for the treatment of diabetes is being reported, initially in the natural distribution area of the species and by the time in other Mexican regions [17]. 


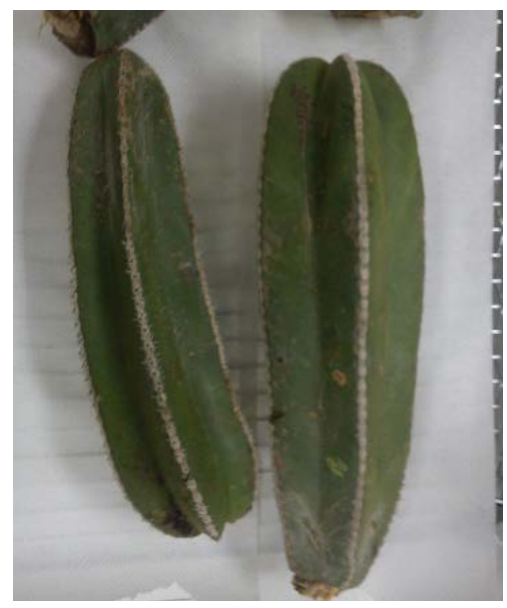

(a)

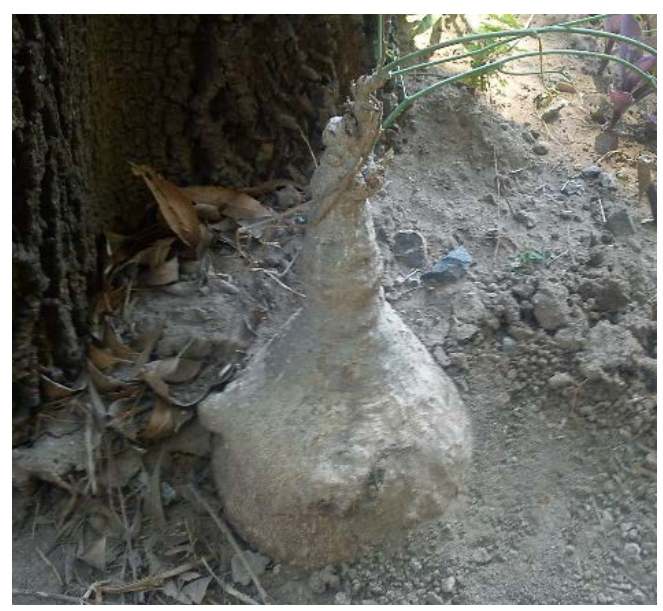

(b)

Figure 1. Pictures of the plants used in this investigation: (a) Pachycereus marginatus (DC.) Britton \& Rose commercially acquired; (b) Ibervillea sonorae (S. Watson) Greene collected at Los Mochis, Sinaloa, Mexico.

\section{Methods and Materials}

\subsection{Plant Material}

Ibervillea sonorae (S. Watson) Greene, popularly called "Guareque”, was collected close to the town of Los Mochis in the Mexican state of Sinaloa in July 2009. Pachycereus marginatus (DC.) Britton \& Rose, also known as "Chilayo", was obtained commercially from the local market "Mercado Juárez" in Monterrey, México, in September 2011. Ibervillea sonorae and Pachycereus marginatus were kindly identified by the Professors M. González-Álvarez (marcela.gonzálezal@uanl.edu.mx) and J.A. Verduzco-Martínez

(jorge.verduzcomr@uanl.edu.mx) from the Facultad de Ciencias Biológicas of the Universidad Autónoma de Nuevo León. Voucher specimens were deposited in the herbarium of the same institute: I. sonorae (025589), P. marginatus (025588).

\subsection{Preparation of Plant Extracts}

Vegetal material of the selected plants was cleaned, dried at room temperature and powdered. The extraction was carried out with methanol as unique solvent. $188 \mathrm{~g}$ of $P$. marginatus were extracted with methanol, using a Soxhlet equipment for $40 \mathrm{~h} \mathrm{(4} \mathrm{portions} \mathrm{of} \mathrm{ca.} 47 \mathrm{~g}$, each charge with $600 \mathrm{~mL}$ solvent). After filtration, the solvent was removed under reduced pressure. With the same procedure, $52 \mathrm{~g}$ of $I$. sonorae were extracted with 600 $\mathrm{mL}$ methanol. These methanolic extracts were submitted to a partition with $n$-hexane and ethyl acetate as described by Pérez-Castorena et al. [18]. Each extract was dissolved in $200 \mathrm{~mL}$ methanol in a $500 \mathrm{~mL}$ separating funnel. Then, $200 \mathrm{~mL}$ hexane was added and stirred vigorously. After the formation of the two immiscible phases, the hexane phase (upper phase) was separated from the methanolic solution. This process was performed in triplicate. Finally, the hexane partition was concentrated under reduced pressure. The recovered methanolic phase was concentrated up to a volume of approximately $50 \mathrm{~mL}$ and was dissolved in $150 \mathrm{~mL}$ of distilled water. This aqueous methanol solution was transferred to a $500 \mathrm{~mL}$ separating funnel, added $200 \mathrm{~mL}$ of ethyl acetate and stirred vigorously. After the formation of the two immiscible phases, the ethyl acetate phase (lower phase) was separated. This process was performed in triplicate. The recovered ethyl acetate partition was concentrated in vacuum. Yields are shown in Table 1.

10 milligrams of each extract was dissolved in $10 \%$ aqueous ethanol to give a solution stock of $1 \mathrm{mg} / \mathrm{mL}$. These solutions were sterilized by filtration using sterile $0.22 \mu \mathrm{m}$ pore size filters (Merck Millipore, Co.) and submitted to cytotoxic assays.

\subsection{Reagents, Culture Media and Cell Lines}

Penicillin-streptomycin solution, L-glutamine, and RPMI 1640 were obtained from Life Technologies (Grand 
Table 1. Direct methanol extraction and partitions of $P$. marginatus and $I$. sonorae.

\begin{tabular}{cccc}
\hline \multirow{2}{*}{ Plant } & \multicolumn{3}{c}{ Extract weight (Yield) } \\
\cline { 2 - 4 } & Methanol & Hexane partition & EtOAc partition \\
\hline Pachycereus marginatus (DC.) Britton \& Rose & $30.4 \mathrm{~g} \mathrm{(16.2 \% )}$ & $1.37 \mathrm{~g} \mathrm{(4.5 \% )}$ & $1.73 \mathrm{~g}(5.88 \%)$ \\
Ibervillea sonorae (S. Watson) Greene & $4.37 \mathrm{~g} \mathrm{(8.4 \% )}$ & $0.11 \mathrm{~g} \mathrm{(2.51 \% )}$ & $2.14 \mathrm{~g}(48.9 \%)$ \\
\hline
\end{tabular}

Island, NY). Fetal bovine serum (FBS), sodium dodecyl sulfate (SDS), $N, N$-dimethylformamide (DMF), PBS, and 3-[4,5-dimethylthiazol-2-yl]-2,5-diphenyltetrazolium bromide (MTT) were purchased from Sigma-Aldrich Co. (St. Louis, MO). The murine lymphoma L5178Y-R (clone CRL-1722) was purchased from the American Type Culture Collection (Rockville, MD) and maintained in RPMI 1640 medium supplemented with 10\% FBS, 1\% L-glutamine, and 0.5\% penicillin-streptomycin solution (referred as complete RPMI 1640 medium). Vincristine (positive control) was obtained from Vintec (Columbia, S.A. de C.V., México, D.F.).

\subsection{Effect of Extracts on Murine Tumor Cell Growth}

L5178Y-R is a cell line derived from a lymphoma induced in female DBA/2 mice treated with 3-methylcholanthrene and has been maintained by passes in vivo in its syngeneic host. The cells are resistant to $\mathrm{X}$-rays but sensitive to UV radiation, also are sensitive to antineoplastic drugs, so they are ideal for cytotoxic activity assessments [19].

To determine the direct in vitro cytotoxic effect of the extracts, exponentially growing lymphoma L5178Y-R cells [20] were plated at $5 \times 10^{4}$ cells/mL in flat-bottomed 96-well plates (Becton Dickinson, Lincoln Park, NJ) in $100 \mu \mathrm{L}$ of complete RPMI 1640 medium. These tumor cell cultures were then incubated for $44 \mathrm{~h}$ at $37^{\circ} \mathrm{C}$ in $5 \%$ $\mathrm{CO}_{2}$ in the presence of different concentrations, ranging from 3.9 to $500 \mu \mathrm{g} / \mathrm{mL}$ of the extracts in a volume of $100 \mu \mathrm{L}$. The extracts were dissolved in $10 \%$ ethanol as explained previously, and vehicles were tested using the same concentration of the solvent but without the extract. Vincristine was used as positive control. After incubation, $15 \mu \mathrm{L}$ of MTT $(0.5 \mathrm{mg} / \mathrm{mL}$ final concentration) were added to all wells, and cultures were additionally incubated for $4 \mathrm{~h}$. Next, the plates were decanted and added $80 \mu \mathrm{L}$ of DMSO to each well. Optical densities were then read in a microplate reader (Bio-Tek Instruments, Inc., Winooski, VT) at $570 \mathrm{~nm}$. The percentage of cytotoxicity was calculated as follows:

$$
\% \text { Cytotoxicity }=100-\left[\left(\mathrm{A}_{570} \text { in extract treated cells } / \mathrm{A}_{570} \text { in untreated cells }\right)(100)\right]
$$

\subsection{Statistics}

Results are expressed as mean \pm SEM of the response of 3 replicate determinations per treatment. Level significance was assessed by Dunnet’s $t$-test. $P<0.05$ was considered significant.

\section{Results}

The in vitro cytotoxic effect of methanolic extracts and partitions of the Mexican plants Pachycereus marginatus (DC.) Britton \& Rose and Ibervillea sonorae (S. Watson) Greene against lymphoma L5178Y-R cells was evaluated.

As shown in Figure 2, the crude methanol extract derived from P. marginatus revealed a remarkable cytotoxic activity against the L5178Y-R cell line with an inhibition up to $92 \%$ at the lowest concentration tested (3.9 $\mu \mathrm{g} / \mathrm{mL}$ ), and it kept this high activity up to the largest concentration of $500 \mu \mathrm{g} / \mathrm{mL}$. The partitions derived from the methanolic extract of $P$. marginatus showed lower cytotoxicity at the lowest concentration tested (hexane up to $16 \%$; ethyl acetate up to $7 \%$ ). On the other side these partitions showed significant $(p<0.05)$ and concentration-dependent cytotoxicity against L5178Y-R cells at concentrations ranging from 7.81 to $500 \mu \mathrm{g} / \mathrm{mL}$ (hexane partition up to $94 \%$ at $500 \mu \mathrm{g} / \mathrm{mL}$; ethyl acetate partition up to $94 \%$ at $65.5 \mu \mathrm{g} / \mathrm{mL}$ ). The partitions from $P$. marginatus showed lower cytotoxic activity than the original methanolic extract at the same concentrations.

The methanolic extract of $I$. sonorae (Figure 3 ) demonstrated a little activity, with an inhibition of $6 \%$ at 3.9 $\mu \mathrm{g} / \mathrm{mL}$, but on the other side showed significant $(p<0.05)$ and concentration-dependent cytotoxicity against L5178Y-R cells at concentrations ranging from 7.81 to $500 \mu \mathrm{g} / \mathrm{mL}$ (up to $63 \%$ at $500 \mu \mathrm{g} / \mathrm{mL}$ ). Hexane partition 


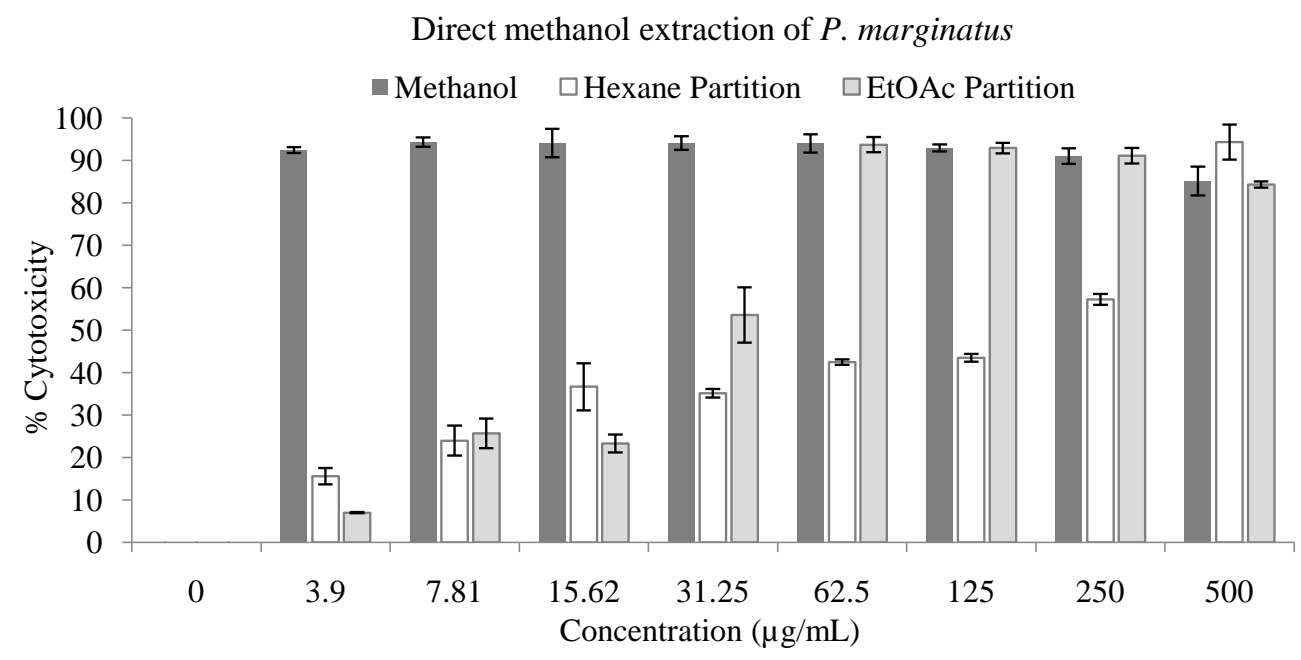

Figure 2. Effect of Pachycereus marginatus (DC.) Britton \& Rose methanolic extract and its partitions over lymphoma L5178Y-R growth. The results are expressed as \% of cytotoxicity. Data are mean \pm SEM of triplicate cultures. Vincristine was used as positive control (data not shown). ${ }^{*} p<0.05$ was considered significant.

Direct methanol extraction of I. sonorae

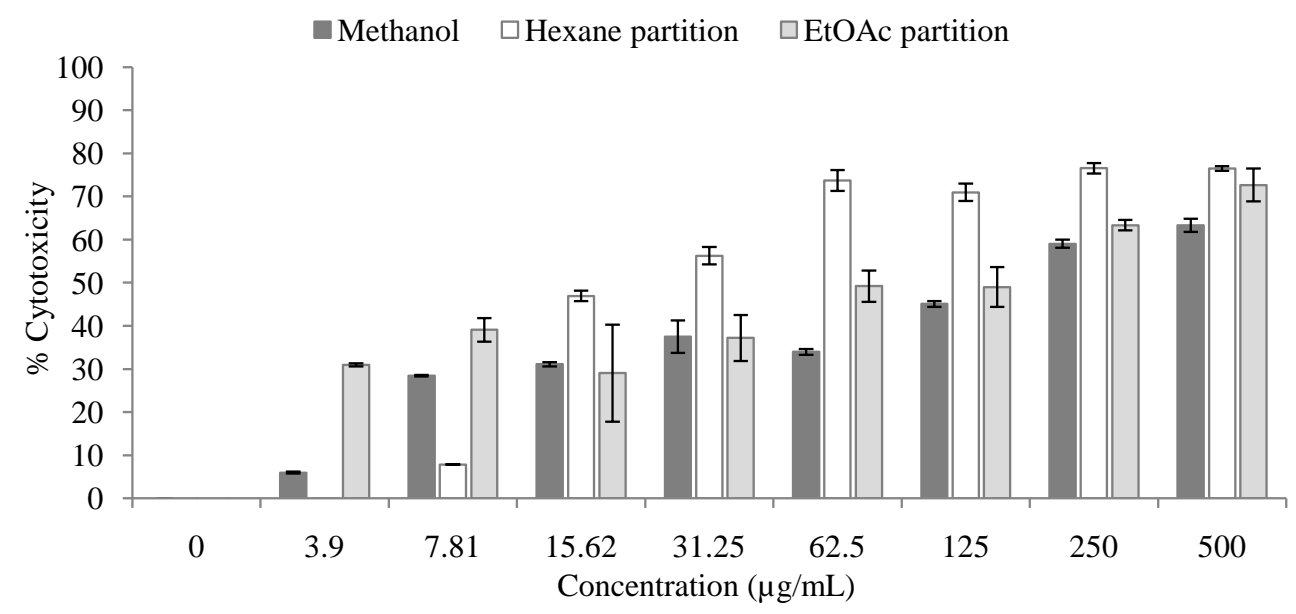

Figure 3. Effect of Ibervillea sonorae (S. Watson) Greene methanolic extract and its partitions over lymphoma L5178Y-R growth. The results are expressed as \% of cytotoxicity. Data are mean \pm SEM of triplicate cultures. Vincristine was used as positive control (data not shown). ${ }^{*} p<0.05$ was considered significant.

derived from the methanolic extract of I. sonorae did not show cytotoxic activity against the L5178Y-R cell line at the lowest concentration tested $(3.9 \mu \mathrm{g} / \mathrm{mL})$, whereas the ethyl acetate partition showed $31 \%$ inhibition at this concentration. Both partitions showed significant $(p<0.05)$ and concentration-dependent cytotoxicity against L5178Y-R cells at concentrations ranging from 7.81 to $500 \mu \mathrm{g} / \mathrm{mL}$ (hexane partition up to $76 \%$ at $250 \mu \mathrm{g} / \mathrm{mL}$; ethyl acetate partition up to $73 \%$ at $500 \mu \mathrm{g} / \mathrm{mL}$ ). The partitions from I. sonorae showed higher cytotoxic activity than the original methanol extract at the same concentrations.

\section{Discussion}

Medicinal plants have played a significant role in the discovery and development of new therapeutic drugs [21]. In the last three decades the interest in phytochemicals and their possible applications in the pharmaceutical industry has been reborn [22] [23]. Nowadays, approximately $30 \%$ of drugs used in industrialized countries come 
from plants or are derived from plant secondary metabolites [24]. Some plants have proven to be an important source of anticancer compounds [25]. A successful case of natural anticancerous agent is Paclitaxel (Taxol), a diterpenoid isolated from the bark of Taxus brevifolia [26].

\subsection{Pachycereus marginatus}

According to the results mentioned above, and taking into account that Vincristine control caused up to 81\% cytotoxicity against L5178Y-R cells at a concentration of $31.25 \mu \mathrm{g} / \mathrm{mL}$ (data not shown), the crude methanol extract of Pachycereus marginatus (DC.) Britton \& Rose revealed a substantial cytotoxic effect against the murine lymphoma L5178Y-R (94\% cytotoxicity at $31.25 \mu \mathrm{g} / \mathrm{mL}$ ) (Table 2). As shown in Figure 2, in general, the partitions derived from the methanol extract of $P$. marginatus showed lower cytotoxic activity than the original extract at the same concentrations. At low concentrations ( 3.9 to $15.62 \mu \mathrm{g} / \mathrm{mL})$ the hexane partitions showed higher cytotoxicity (up to 37\%) than the ethyl acetate partitions, but starting from $31.5 \mu \mathrm{g} / \mathrm{mL}$ this situation was reversed and the partitions of ethyl acetate significantly increased their cytotoxic against the murine lymphoma L5178Y-R (up to 94\%) with respect to the hexane partitions. At $31.25 \mu \mathrm{g} / \mathrm{mL}$, no partition of P. marginatus surpassed the cytotoxic activity of Vincristine control (hexanepartition up to 35\%; ethyl acetate partition up to 53\%; Vincristine up to 81\%). This relationship between cytotoxicity and concentration of methanol extract and partitions of $P$. marginatus suggests that the plant possesses active compounds of a wide range of polarities and that they work synergistically to confer its high activity to the crude methanolic extract, even at the lowest concentrations tested (3.9 to $31.25 \mu \mathrm{g} / \mathrm{mL}$ ).

The Cactaceae family comprises more than 1500 species, but until recently only a few of them have been tested for their chemopreventive and anticancer attributes [27]. Mexico has the greatest richness of these plants, with 913 taxa, $80 \%$ of which are endemic to the country [28]. It has been reported the biological activity of aqueous extracts of Lophocereus schottii, a cactus phylogenetic related to P. marginatus [29], against bacteria of medical importance and the human cervical cancer HeLa cell line [30]. Orozco-Barocio et al. [31] validated that the ethanolic extract of $L$. schottii had an effect on L5178Y murine cells lymphoma. There is to date no report of similar biological activity of $P$. marginatus.

As said before, phylogenetic studies have shown that $P$. marginatus is highly related to Lophocereus schottii, and their relationship became more evident due to similar results on chemotaxonomic experiments. Similar alkaloids have been isolated from both cacti [32] [33]. Cactus alkaloids are of simple chemical constitution. They are either substituted $\beta$-phenylethylamines, tetrahydroisoquinolines or 1-methyltetrahydroisoquinolines [34]. The alkaloids of $L$. schottii and $P$. marginatus, however, are unique among the isoquinoline alkaloids by having an isobutyl group at C-1 [35], e.g. lophocerine and pilocereine, the last one being trimeric and is presumed to arise from lophocerine [36].

Isoquinoline alkaloids isolated from different natural sources have shown important cytotoxic and anti-carcinogenic activities [37] [38]. Lophocerine and pilocereine (compounds of high polarity), both found in $L$. schottii and $P$. marginatus, might be responsible for the cytotoxic activity of these cacti.

Table 2. Effect of P. marginatus methanolic extract and its partitions on L5178Y-R cells toxicity.

\begin{tabular}{cccc}
\hline Concentration $(\boldsymbol{\mu g} / \mathbf{m L})$ & P. marginatus cytotoxicity & Hexane partition & EtOAc partition \\
\hline 3.9 & $92.43 \pm 0.7^{*}$ & $15.62 \pm 1.94^{* *}$ & $7.03 \pm 0.16^{* *}$ \\
7.8 & $94.31 \pm 1.1^{* *}$ & $24.01 \pm 3.5^{*}$ & $25.71 \pm 3.46^{*}$ \\
15.62 & $94.12 \pm 3.3^{* *}$ & $36.71 \pm 5.54^{*}$ & $23.30 \pm 2.13^{* *}$ \\
31.25 & $94.16 \pm 1.6^{* *}$ & $35.16 \pm 1.0^{* *}$ & $53.61 \pm 6.49^{* *}$ \\
62.5 & $94.05 \pm 2.1^{* *}$ & $42.49 \pm 0.61^{* *}$ & $93.74 \pm 1.82^{* *}$ \\
125 & $92.96 \pm 0.8^{* *}$ & $43.55 \pm 0.92^{* *}$ & $92.93 \pm 1.27^{*}$ \\
250 & $91.07 \pm 1.8^{* *}$ & $57.26 \pm 1.26^{* *}$ & $91.09 \pm 1.83^{* *}$ \\
500 & $85.20 \pm 3.4^{* *}$ & $94.37 \pm 4.12$ & $84.33 \pm 0.74^{* *}$ \\
\hline
\end{tabular}

Effect of Pachycereus marginatus (DC.) Britton \& Rose methanolic extract and its partitions over lymphoma L5178Y-R growth. The results are expressed as $\%$ of cytotoxicity. Data are mean \pm SEM of triplicate cultures. Vincristine was used as positive control (data not shown). ${ }^{*} p<0.05,{ }^{* *} p<$ 0.01 . 


\subsection{Ibervillea sonorae}

Ibervillea sonorae (S. Watson) Greene biological results reveal a lower cytotoxicity in comparison to the cactus, but important as well ( $38 \%$ cytotoxicity at $31.25 \mu \mathrm{g} / \mathrm{mL}$; Vincristine control up to $81 \%$ at the same concentration) (Table 3). As shown in Figure 3, in general, the partitions derived from the methanol extract of I. sonorae showed higher cytotoxic activity than the original extract at the same concentrations. At low concentrations (3.9 to $7.81 \mu \mathrm{g} / \mathrm{mL}$ ) the ethyl acetate partitions showed higher cytotoxicity (up to $38 \%$ ) than the hexane partitions, but starting from $15.62 \mu \mathrm{g} / \mathrm{mL}$ this situation was reversed and the partitions of hexane significantly increased their cytotoxic activity (up to 67\%) with respect to the ethyl acetate partitions. At $31.25 \mu \mathrm{g} / \mathrm{mL}$, no partition of $I$. sonorae surpassed the cytotoxic activity of Vincristine control (hexanepartition up to 56\%; ethyl acetate partition up to $37 \%$; Vincristine up to $81 \%$ ). These results might indicate that the active compounds in I. sonorae are those of low and medium polarity.

Cucurbitaceae, commonly known as cucurbits or gourds, are a family of 95 genera in 15 tribes comprising 940 to 980 species that are essentially distributed in the tropical and subtropical regions, with hotspots of diversity in Southeast Asia, West Africa, Madagascar, and Mexico [39]. There are about 148 species of Cucurbitaceae in Mexico [40]. Although the roots and the fruits of these Cucurbitaceae species are very bitter, they have been used as folk medicines in some countries because of their wide spectrum of pharmacological activities such as anti-inflammation and anticancer effects.

Ibervillea sonorae has been used mainly to treat diabetes due to its hypoglycemic activity [41]-[43]. RuizBustos et al. [44] evaluated the antimicrobial activity of I. sonorae against fungi as well as Gram-positive and Gram-negative bacteria. The cytotoxicity of aqueous extracts of $I$. sonorae against human cervix cancer and human breast cancer has been investigated [45], and a recent study showed that the methanol extract and hexane and ethyl acetate fractions of $I$. sonorae exhibit potent anti-proliferative activity against HeLa, M12AK.C3F6, A549, and RAW 264.7 cancer cell lines [46]. Nevertheless, its cytotoxicity against L5178Y-R has never been established up to now.

During the last decades, a large number of cucurbitacins have been isolated from various plant species belonging to the Cucurbitaceae. More than 50 cucurbitacins have been identified, and they exhibit a wide variety of biological activities that include, but are not limited to, cytotoxicity, antiproliferation, anti-inflammation, antioxidant, antihepatotoxicity, antibacterial and antiviral properties, as well as antimetastatic properties and improved anticancer activity when combined with current chemotherapies [47]-[49]. In the last ten years, cucurbitacins have shown to inhibit proliferation and induced apoptosis utilizing an extended array of in vitro and in vivo cancer cell models [50] [51].

From I. sonorae many cucurbitanes and cucurbitane-type glycosides have been isolated, e.g. Kinoins A-C [46] [52]-[54] and these cucurbitacins (compounds of medium polarity) might be responsible for the cytotoxic activity of $I$. sonorae observed in this research.

Table 3. Effect of $I$. sonorae methanolic extract and its partitions on L5178Y-R cells toxicity.

\begin{tabular}{cccc}
\hline Concentration $(\boldsymbol{\mu} / \mathbf{m L})$ & I. sonorae cytotoxicity & Hexane partition & EtOAc partition \\
\hline 3.9 & $5.98 \pm 0.22$ & 0 & $30.98 \pm 0.34^{*}$ \\
7.8 & $28.45 \pm 0.19^{*}$ & $7.87 \pm 0.08$ & $39.11 \pm 2.72$ \\
15.62 & $31.14 \pm 0.49^{*}$ & $46.98 \pm 1.23^{* *}$ & $29.07 \pm 11.24$ \\
31.25 & $37.54 \pm 3.76$ & $56.28 \pm 2.02^{*}$ & $37.21 \pm 5.33$ \\
62.5 & $34.01 \pm 0.68$ & $73.77 \pm 2.43^{* *}$ & $49.25 \pm 3.64$ \\
125 & $45.12 \pm 0.66^{*}$ & $71.02 \pm 2.01$ & $49.03 \pm 4.6$ \\
250 & $59.09 \pm 0.97^{* *}$ & $76.59 \pm 1.20^{*}$ & $63.39 \pm 1.18^{*}$ \\
500 & $63.38 \pm 1.54^{*}$ & $76.54 \pm 0.54$ & $72.70 \pm 3.82^{*}$ \\
\hline
\end{tabular}

Effect Ibervillea sonorae (S. Watson) Greene methanolic extract and its partitions over lymphoma L5178Y-R growth. The results are expressed as \% of cytotoxicity. Data are mean \pm SEM of triplicate cultures. Vincristine was used as positive control (data not shown). ${ }^{*} p<0.05,{ }^{* *} p<0.01$. 


\section{Conclusion}

The studies presented in this article unveil the extraordinary therapeutic potential of two Mexican desert plants. The results demonstrate that the methanol extracts and partitions from $P$. marginatus and I. sonorae possess cytotoxic activity against the murine lymphoma L5178Y-R and may validate the ethnobotanical use of these plants for the treatment of diseases associated with cancer [7]. Cancer prevention or chemotherapy based on extracts or pure compounds derived from desert plants with known cancer-inhibiting properties might lead to promising alternatives to current cancer therapy. The cytotoxic activity of these plants could arise due to the occurrence of isoquinoline alkaloids in P. marginatus as well as cucurbitacins in $I$. sonorae, as is described in the scientific literature. Whereas single targeted chemotherapeutic drugs commonly lack efficacy and invoke drug resistance and adverse effects in cancer patients, traditional herbal medicines are seen as bright prospects for treating complex diseases, such as lymphoblastic leukemia, in a systematic and holistic manner [55]-[57]. Further studies on the mechanisms of biological effects by which the extract exerts their cytotoxic effects are necessary. Given the high increase in the main types of cancer, it also needs to intensify studies on the capabilities of desert plants for the combat of this disease.

\section{Acknowledgements}

The authors would like to thank CONACYT (Mexico for doctoral fellowships awarded to R.M.C. and M.A.S.E.). We also thank the Universidad Autónoma de Nuevo León (Mexico) for PAICYT grants CN-422-10 and CN-662-11.

\section{References}

[1] Bazrafshan, N. and Lotfi, M.M. (2016) A Multi-Objective Multi-Drug Model for Cancer Chemotherapy Treatment Planning: A Cost-Effective Approach to Designing Clinical Trials. Computers \& Chemical Engineering, 87, 226-233. http://dx.doi.org/10.1016/j.compchemeng.2015.12.004

[2] WHO (2015) Cancer Key Facts. World Health Organization, Geneva. http://www.who.int/mediacentre/factsheets/fs297/en/

[3] Gröpper, S., van der Meer, E., Landes, T., Bucher, H., Stickel, A. and Goerling, U. (2016) Assessing Cancer-Related Distress in Cancer Patients and Caregivers Receiving Outpatient Psycho-Oncological Counseling. Supportive Care in Cancer, 24, 2351-2357. http://dx.doi.org/10.1007/s00520-015-3042-9

[4] Soto-Perez-de-Celis, E. and Chavarri-Guerra, Y. (2016) National and Regional Breast Cancer Incidence and Mortality Trends in Mexico 2001-2011: Analysis of a Population-Based Database. Cancer Epidemiology, 41, 24-33. http://dx.doi.org/10.1016/j.canep.2016.01.007

[5] Aarland, R.C., Peralta-Gómez, S., Sanchéz, C.M., Parra-Bustamante, F., Villa-Hernández, J.M., de León-Sánchez, F.D., Pérez-Flores, L.J., Rivera-Cabrera, F. and Mendoza-Espinoza, J.A. (2015) A Pharmacological and Phytochemical Study of Medicinal Plants Used in Mexican Folk Medicine. Indian Journal of Traditional Knowledge, 14, 550-557.

[6] Alonso-Castro, A.J., Villarreal, M.L., Salazar-Olivo, L.A., Gomez-Sanchez, M., Dominguez, F. and Garcia-Carranca, A. (2011) Mexican Medicinal Plants Used for Cancer Treatment: Pharmacological, Phytochemical and Ethnobotanical Studies. Journal of Ethnopharmacology, 133, 945-972. http://dx.doi.org/10.1016/j.jep.2010.11.055

[7] Lopez-Moreno, C. and Quintanilla-Licea, R. (2012) Phytotherapy with Angiosperms from Arid Zones of Northern Mexico in Patients with Malignant and Benign Tumors. European Journal of Cancer, 48, S178. http://dx.doi.org/10.1016/s0959-8049(12)71388-6

[8] Arias, S. and Terrazas, T. (2009) Taxonomic Revision of Pachycereus (Cactaceae). Systematic Botany, 34, 68-83. http://dx.doi.org/10.1600/036364409787602384

[9] BDMTM-Pm (2015) Pachycereus Marginatus. Biblioteca Digital de La Medicina Tradicional Mexicana. http://www.medicinatradicionalmexicana.unam.mx/monografia.php?l=3\&t=Stenocereusmarginatus\&id=7891

[10] Bravo-Hollis, H. (1978) Las Cactáceas de México. 2nd Edition, Universidad Nacional Autónoma de México, Mexico.

[11] Arias-Toledo, A.A., Valverde-Valdés, M.T. and Reyes-Santiago, J. (2000) Las Plantas de La Región de Zapotitlán Salinas, Puebla. CONABIO-SEMARNAP, Mexico.

[12] Shetty, A.A., Rana, M.K. and Preetham, S.P. (2012) Cactus: A Medicinal Food. Journal of Food Science and Technology, 49, 530-536. http://dx.doi.org/10.1007/s13197-011-0462-5

[13] BDMTM-Ls (2015) Lophocereus Schottii. Biblioteca Digital de La Medicina Tradicional Mexicana. http://www.medicinatradicionalmexicana.unam.mx/monografia.php?l=3\&t=\&id=7982 
[14] Breslin, P.B. (2015) Published Research in Cacti and Succulents, 2014-June 2015: A (Briefly) Annotated, Selected Bibliography. Haseltonia, 21, 112-124. http://dx.doi.org/10.2985/026.021.0101

[15] BDMTM-Is (2015) Ibervillea Sonorae. Biblioteca Digital de La Medicina Tradicional Mexicana. http://www.medicinatradicionalmexicana.unam.mx/flora2.php?l=4\&t=Guareque\&po=\&id=6693\&clave_region=8

[16] Emerson, J.T. and Welker, W.H. (1909) Some Notes on the Chemical Toxicity of Ibervillea Sonorae. Journal of Biological Chemistry, 5, 339-350.

[17] Aguilar-Contreras, A. and Xolalpa-Molina, S. (2002) La Herbolaria Mexicana En El Tratamiento de La Diabetes. Ciencia, 53, 24-35.

[18] Pérez-Castorena, A.L., Oropeza, R.F., Vázquez, A.R., Martínez, M. and Maldonado, E. (2006) Labdanes and Withanolides from Physalis Coztomatl. Journal of Natural Products, 69, 1029-1033. http://dx.doi.org/10.1021/np0601354

[19] Beer, J.Z., Jacobson, E.D., Evans, H.H. and Szumiel, I. (1984) X-Ray and UV Mutagenesis in Two L5178Y Cell Strains Differing in Tumorigenicity, Radiosensitivity, and DNA Repair. British Journal of Cancer, 49, 107-111.

[20] Gomez-Flores, R., Quintanilla-Licea, R., Verde-Star, M.J., Morado-Castillo, R., Vázquez-Díaz, D., Tamez-Guerra, R., Tamez-Guerra, P. and Rodríguez-Padilla, C. (2012) Long-Chain Alkanes and Ent-Labdane-Type Diterpenes from Gymnosperma glutinosum with Cytotoxic Activity against the Murine Lymphoma L5178Y-R. Phytotherapy Research, 26, 1632-1636. http://dx.doi.org/10.1002/ptr.4625

[21] Chen, J., Wu, Q., Hawas, U.W. and Wang, H. (2016) Genetic Regulation and Manipulation for Natural Product Discovery. Applied Microbiology and Biotechnology, 100, 2953-2965. http://dx.doi.org/10.1007/s00253-016-7357-3

[22] Butler, M.S., Robertson, A.A.B. and Cooper, M.A. (2014) Natural Product and Natural Product Derived Drugs in Clinical Trials. Natural Product Reports, 31, 1612-1661. http://dx.doi.org/10.1039/C4NP00064A

[23] Szychowski, J., Truchon, J.F. and Bennani, Y.L. (2014) Natural Products in Medicine: Transformational Outcome of Synthetic Chemistry. Journal of Medicinal Chemistry, 57, 9292-9308. http://dx.doi.org/10.1021/jm500941m

[24] Newman, D.J. and Cragg, G.M. (2016) Natural Products as Sources of New Drugs from 1981 to 2014. Journal of Natural Products, 79, 629-661. http://dx.doi.org/10.1021/acs.jnatprod.5b01055

[25] Cragg, G.M., Grothaus, P.G. and Newman, D.J. (2014) New Horizons for Old Drugs and Drug Leads. Journal of Natural Products, 77, 703-723. http://dx.doi.org/10.1021/np5000796

[26] Wani, M.C. and Horwitz, S.B. (2014) Nature as a Remarkable Chemist: A Personal Story of the Discovery and Development of Taxol. Anticancer Drugs, 25, 482-487. http://dx.doi.org/10.1097/CAD.0000000000000063

[27] Harlev, E., Nevo, E., Solowey, E. and Bishayee, A. (2013) Cancer Preventive and Curative Attributes of Plants of the Cactaceae Family : A Review. Planta Medica, 79, 713-722. http://dx.doi.org/10.1055/s-0032-1328632

[28] Jiménez Sierra, C.L. (2011) Las Cactáceas Mexicanas Y Los Riesgos Que Enfrentan. Revista Digital Universitaria, 12, $1-23$.

[29] Hartmann, S., Nason, J.D. and Bhattacharya, D. (2002) Phylogenetic Origins of Lophocereus (Cactaceae) and the Senita Cactus-Senita Moth Pollination Mutualism. American Journal of Botany, 89, 1085-1092. http://dx.doi.org/10.3732/ajb.89.7.1085

[30] Morales-Rubio, M.E., Verde-Star, J., Oranday-Cárdenas, A., Rivas-Morales, C., Arévalo-Niño, K., Treviño-Neávez, J.F., Carranza-Rosales, P. and Cruz-Vega, D.E. (2007) Actividad Biológica de Lophocereus schottii (Engelm) Britton and Rose. Revista Salud Pública Y Nutrición, 1-3.

[31] Orozco-Barocio, A., Paniagua-Dominguez, B.L., Benítez-Saldaña, P.A., Flores-Torales, E., Velázquez-Magaña, S. and Arreola-Nava, H.J. (2013) Cytotoxic Effect of the Ethanolic Extract of Lophocereus Schotti: A Mexican Medicinal Plant. African Journal of Traditional, Complementary and Alternatives Medicines, 10, 397-404.

[32] Dembitsky, V.M., Gloriozova, T.A. and Poroikov, V.V. (2014) Naturally Occurring Plant Isoquinoline N-Oxide Alkaloids: Their Pharmacological and SAR Activities. Phytomedicine, 22, 183-202. http://dx.doi.org/10.1016/j.phymed.2014.11.002

[33] Djerassi, C., Brewer, H.W., Clarke, C. and Durham, L.J. (1962) Alkaloid Studies. XXXVIII. Pilocereine-A Trimeric Cactus Alkaloid. Journal of the American Chemical Society, 84, 3210-3212. http://dx.doi.org/10.1021/ja00875a052

[34] Reti, L. (1950) Cactus Alkaloids and Some Related Compounds. In: Zechmeister, L., Ed., Progress in the Chemistry of Organic Compounds, Springer Verlag, Wien, 242-289. http://dx.doi.org/10.1007/978-3-7091-7175-2_4

[35] O’Donovan, D.G. and Barry, E. (1974) Biosynthesis of Lophocerine in Lophocereus schottii. Part II. Journal of the Chemical Society, Perkin Transactions I: Organic and Biorganic Chemistry, 2528-2529. http://dx.doi.org/10.1039/p19740002528

[36] Schütte, H.R. and Seelig, G. (1969) Zur Biosynthese von Pilocerein Und Lophocerin. Liebigs Annalen der Chemie, 730, 186-190. http://dx.doi.org/10.1002/jlac.19697300119 
[37] Kartsev, V.G. (2004) Natural Compounds in Drug Discovery. Biological Activity and New Trends in the Chemistry of Isoquinoline Alkaloids. Medicinal Chemistry Research, 13, 325-336. http://dx.doi.org/10.1007/s00044-004-0038-2

[38] Stévigny, C., Bailly, C. and Quetin-Leclercq, J. (2005) Cytotoxic and Antitumor Potentialities of Aporphinoid Alkaloids. Current Medicinal Chemistry—Anti-Cancer Agents, 5, 173-182. http://dx.doi.org/10.2174/1568011053174864

[39] Schaefer, H. and Renner, S.S. (2011) Cucurbitaceae. In: Kubitzki, K., Ed., The Families and Genera of Vascular Plants, Vol. 10, Springer Verlag, Berlin, 112-174.

[40] Lira, R. and Rodríguez-Arévalo, I. (2006) Catálogo de Autoridades Taxonómicas de Las Cucurbitáceas (Cucurbitaceae: Magnoliopsida) de México. Facultad de Estudios Superiores Iztacala, UNAM, SNIB-CONABIO, Mexico.

[41] Andrade-Cetto, A. and Heinrich, M. (2005) Mexican Plants with Hypoglycaemic Effect Used in the Treatment of Diabetes. Journal of Ethnopharmacology, 99, 325-348. http://dx.doi.org/10.1016/j.jep.2005.04.019

[42] Rivera-Ramírez, F., Escalona-Cardoso, G.N., Garduño-Siciliano, L., Galaviz-Hernández, C. and Paniagua-Castro, N. (2011) Antiobesity and Hypoglycaemic Effects of Aqueous Extract of Ibervillea sonorae in Mice Fed a High-Fat Diet with Fructose. Journal of Biomedicine and Biotechnology, 2011, Article ID: 968984. http://dx.doi.org/10.1155/2011/968984

[43] Zapata-Bustos, R., Alonso-Castro, Á.J., Gómez-Sánchez, M. and Salazar-Olivo, L.A. (2014) Ibervillea sonorae (Cucurbitaceae) Induces the Glucose Uptake in Human Adipocytes by Activating a PI3K-Independent Pathway. Journal of Ethnopharmacology, 152, 546-552. http://dx.doi.org/10.1016/j.jep.2014.01.041

[44] Ruiz-Bustos, E., Velázquez, C., Garibay-Escobar, A., García, Z., Plascencia-Jatomea, M., Cortez-Rocha, M.O., Hernández-Martínez, J. and Robles-Zepeda, R.E. (2009) Antibacterial and Antifungal Activities of Some Mexican Medicinal Plants. Journal of Medicinal Food, 12, 1398-1402. http://dx.doi.org/10.1089/jmf.2008.0205

[45] Vega-Avila, E., Espejo-Serna, A., Alarcón-Aguilar, F. and Velasco-Lezama, R. (2009) Cytotoxic Activity of Four Mexican Medicinal Plants. Proceedings of the Western Pharmacology Society, 52, 78-82.

[46] Torres-Moreno, H., Velázquez, C.A., Garibay-Escobar, A., Curini, M., Marcotullio, M.C. and Robles-Zepeda, R.E. (2015) Antiproliferative and Apoptosis Induction of Cucurbitacin-Type Triterpenes from Ibervillea sonorae. Industrial Crops and Products, 77, 895-900. http://dx.doi.org/10.1016/j.indcrop.2015.09.055

[47] Attard, E. and Martinoli, M.G. (2015) Cucurbitacin E, an Experimental Lead Triterpenoid with Anticancer, Immunomodulatory and Novel Effects against Degenerative Diseases: A Mini-Review. Current Topics in Medicinal Chemistry, 15, 1708-1713. http://dx.doi.org/10.2174/1568026615666150427121331

[48] El-Senduny, F.F., Badria, F.A., EL-Waseef, A.M., Chauhan, S.C. and Halaweish, F. (2015) Approach for Chemosensitization of Cisplatin-Resistant Ovarian Cancer by Cucurbitacin B. Tumor Biology, 37, 685-698. http://dx.doi.org/10.1007/s13277-015-3773-8

[49] Hall, J.A., Seedarala, S., Rice, N., Kopel, L., Halaweish, F. and Blagg, B.S.J. (2015) Cucurbitacin D Is a Disruptor of the HSP90 Chaperone Machinery. Journal of Natural Products, 78, 873-879. http://dx.doi.org/10.1021/acs.jnatprod.5b00054

[50] Alghasham, A.A. (2013) Cucurbitacins-A Promising Target for Cancer Therapy. International Journal of Health Sciences, Qassim University, 7, 77-89. http://dx.doi.org/10.12816/0006025

[51] Lee, D.H., Iwanski, G.B. and Thoennissen, N.H. (2010) Cucurbitacin: Ancient Compound Shedding New Light on Cancer Treatment. The Scientific World Journal, 10, 413-418. http://dx.doi.org/10.1100/tsw.2010.44

[52] Achenbach, H., Horn, K., Dominguez, X.A., Rombold, C. and Gómez-López, E.G. (1993) Cucurbitanes and Cucurbitane-Type Glycosides from Ibervillea sonorae. Phytochemistry, 33, 437-445. http://dx.doi.org/10.1016/0031-9422(93)85535-Y

[53] Jardón-Delgado, A., Magos-Guerrero, G.A. and Martínez-Vázquez, M. (2014) Isolation of a New Anti-Inflammatory 20, 21, 22, 23, 24, 25, 26, 27-Octanorcucurbitacin-Type Triterpene from Ibervillea sonorae. Natural Products Communications, 9, 15-16.

[54] Weckert, E., Hümmer, K., Dominguez, X.A., Horn, K. and Achenbach, H. (1993) The Absolute Configuration of Kinoin C. Phytochemistry, 33, 447-448. http://dx.doi.org/10.1016/0031-9422(93)85536-Z

[55] Apaya, M.K., Chang, M.-T. and Shyur, L.-F. (2016) Phytomedicine Polypharmacology: Cancer Therapy through Modulating the Tumor Microenvironment and Oxylipin Dynamics. Pharmacology \& Therapeutics, 162, 58-68. http://dx.doi.org/10.1016/j.pharmthera.2016.03.001

[56] Jaffe, E.S. (2009) The 2008 WHO Classification of Lymphomas: Implications for Clinical Practice and Translational Research. Hematology, 2009, 523-531. http://dx.doi.org/10.1182/asheducation-2009.1.523

[57] Layton-Tovar, C.F. and Mendieta-Zerón, H. (2016) Intracellular Signaling Pathways Involved in Childhood Acute Lymphoblastic Leukemia, Molecular Targets. Indian Journal of Hematology and Blood Transfusion, 32, 141-153. http://dx.doi.org/10.1007/s12288-015-0609-z 


\section{Submit or recommend next manuscript to SCIRP and we will provide best service for you:}

Accepting pre-submission inquiries through Email, Facebook, LinkedIn, Twitter, etc.

A wide selection of journals (inclusive of 9 subjects, more than 200 journals)

Providing 24-hour high-quality service

User-friendly online submission system

Fair and swift peer-review system

Efficient typesetting and proofreading procedure

Display of the result of downloads and visits, as well as the number of cited articles

Maximum dissemination of your research work

Submit your manuscript at: http://papersubmission.scirp.org/ 